\title{
Combined hysterolaparoscopy as an early option for initial evaluation of female infertility: a retrospective study of 135 patients
}

\author{
Jasmina Begum*, Sunita Samal, Seetesh Ghose, Pallavee Palai, Rupal Samal
}

Department of Obstetrics and Gynecology, Mahatma Gandhi Medical College and Research Institute, Puducherry607402, India

Received: 26 February 2015

Revised: 25 March 2015

Accepted: 19 April 2015

*Correspondence:

Dr. Jasmina Begum,

E-mail: jasminaaly@gmail.com

Copyright: $\odot$ the author(s), publisher and licensee Medip Academy. This is an open-access article distributed under the terms of the Creative Commons Attribution Non-Commercial License, which permits unrestricted non-commercial use, distribution, and reproduction in any medium, provided the original work is properly cited.

\begin{abstract}
Background: The aim of this study was to find out different causes of female infertility with diagnostic approach using laparoscopy and hysteroscopy.

Methods: This retrospective study was done in the Department of Obstetrics and Gynecology of MGMCRI, Puducherry. 135 infertile women aged 19-40 years were enrolled retrospectively for combined laparoscopy and hysteroscopy. These infertile women were confirmed to have normal ovulatory cycles, hormonal assays and seminogram report. Patient with active genital tract infection and any contraindication to hysterolaparoscopy procedure were excluded. Dye studies as well as inspection for abnormal pelvic and intrauterine pathology and necessary therapeutic interventions were done during the procedure. Abnormal pelvic and intrauterine pathology by hysterolaparoscopy were categorized. Data was statistically analyzed using SPSS software version 15; a result of P $<0.05$ was considered as significant.

Results: Out of 135 cases, $65 \%$ patients had primary and $34.8 \%$ patients had secondary infertility. As a whole pelvic pathology were confirmed in $54.5 \%$ and intrauterine pathology in $20.7 \%$ patients by hysterolaparoscopy. The most common laparoscopic abnormality detected was tubal pathology $40 \%$, followed by pelvic inflammatory disease $18.5 \%$, ovarian pathology $8.1 \%$ pelvic endometriosis $4.4 \%$, and uterine pathology $4.4 \%$ in infertile patients. In hysteroscopy, the incidence of uterine anomaly was $9.6 \%$ and intrauterine septum is the most common anomaly with a mean incidence of approximately $84 \%$ in both the group of infertile patients.

Conclusions: Hysterolaparoscopy is an effective diagnostic tool for evaluation of certain significant and correctable abnormalities in pelvis, tubes and the uterus which are usually missed by other imaging modalities.
\end{abstract}

Keywords: Hysteroscopy, Laparoscopy, Infertility

\section{INTRODUCTION}

Infertility is defined as failure to conceive during one year of unprotected frequent intercourse. It affects approximately $10-15 \%$ of couples. Leading cause of infertility includes tuboperitoneal disease (40 -50\%), ovulatory disorders $(30-40 \%)$, uterine factor $(15-20 \%)$, and male factor infertility $(30-40 \%))^{1,2}$ Less invasive diagnostic tests such as patient's history, pelvic sonography, hysterosalphingography, chylamydia antibodies testing are available but it is still matter of debate how the value of these tests can be compared with hysterolaparoscopy in work up for infertility. Infertile women with normal ovulatory cycles, normal sonography and normal seminogram reports, subtle endometrial changes and tuboperitoneal pathology can highly influence fertility. Hysterolaparoscopy is an excellent 
diagnostic modality to detect hidden pathology in patients without any overt clinical manifestations. Diagnostic hysterolaparoscopy is a modality for long standing infertile cases and not for early infertile cases. Laparoscopy can reveal the presence of peritubal adhesion, periadnexal adhesion, tubal pathology and endometriosis in 35-68\% of cases even after normal HSG. ${ }^{1}$ Diagnostic hysteroscopy is an equally important modality of investigation for female infertility. ${ }^{3}$

Keeping this in view, the present study was designed to assess the role of hysterolaparoscopy in comprehensive work up of infertility, which would help in planning appropriate management.

\section{METHODS}

This study was conducted in the department of Obstetrics and Gynecology in a tertiary care hospital from January 2011 to December 2013 retrospectively. All the infertile patients who underwent diagnostic hysterolaparoscopy in the above mentioned period fulfilling the following criteria were included in this study, 1) women aged 19-40 years 2) primary or secondary infertility as per WHO criterion 3) confirmed ovulatory cycle based on premenstrual endometrial biopsy and also by normal serum level of TSH, FSH, LH, prolactin, progesterone 4) normal seminogram. The data collected were demographic factors such as age, duration and type of infertility, premenstrual endometrial biopsy report and mid luteal progesterone level to confirm ovulatory cycle, base line hormonal profile and records of male evaluation. Intraoperative finding, surgical interventions and complications during procedure were noted. The following parameters such as tubal occlusion, peritubal, periadnexal and dense pelvic adhesions, endometriosis, enlarged ovary or ovarian cyst during laparoscopy and abnormality of cervical canal, uterine cavity, bilateral tubal ostium and endometrium during hysteroscopy were noted. Data was statistically analyzed using SPSS software version 15; values were expressed as percentages, mean $\pm \mathrm{SD}$ and statistically analysis was performed by Fisher's test. A result of $\mathrm{P}<0.05$ was considered as significant.

\section{RESULTS}

Out of 135 patients, who fulfilled the eligibility criteria, $88(65 \%)$ women had primary infertility and $47(34.8 \%)$ had secondary infertility. The mean age of the patients in secondary infertility group were $28.21 \pm 3.66$ years. The patients in secondary infertility group were older compared to primary infertility group having mean age of $21.21 \pm 6.68$ years. The $P$ value is less than 0.0001 this difference is statistically significant.

The mean duration of infertility in primary and secondary group were $3.44 \pm 1.95$ years and $4.66 \pm 2.29$ years, the $\mathrm{P}$ value is equals to 0.0014 and the difference is also significant.
In primary infertility group $48(54.5 \%)$ patients had abnormal findings. Laparoscopy alone detected pelvic abnormalities which were seen in $33(68.7 \%)$ patients. Hysteroscopy alone detected intrauterine abnormalities in $3(6.25 \%)$ patients. About $12(25 \%)$ patients had combined intrauterine and pelvic abnormalities by both laparoscopic and hysteroscopic examination. In secondary infertility group $28(59.5 \%)$ patients had abnormal findings. Similar to primary infertility group, laparoscopy alone detected abnormalities which was seen in $15(31.9 \%)$ patients, hysteroscopy alone abnormalities seen in $4(8.5 \%)$ patients and $9(19.1 \%)$ patients had combined intrauterine and pelvic abnormalities by both laparoscopic and hysteroscopic examination. None of the above values between primary and secondary infertility were statistically significant (Table 1).

Table 1: Prevalence of laparoscopy, hysteroscopy and combined hysteroscopy and laparoscopy abnormalities.

\begin{tabular}{|llll|}
\hline Procedures & $\begin{array}{l}\text { Primary } \\
\text { infertility } \\
(88)\end{array}$ & $\begin{array}{l}\text { Secondary } \\
\text { infertility } \\
(47)\end{array}$ & P value \\
\hline Laparoscopy & $33(37.5 \%)$ & $15(31.9 \%)$ & $0.575(0.417)$ \\
\hline Hysteroscopy & $3(3.4 \%)$ & $4(8.5 \%)$ & $0.237(1.622)$ \\
\hline $\begin{array}{l}\text { Combined } \\
\text { hysteroscopy } \\
\text { \& laparoscopy }\end{array}$ & $12(13.6 \%)$ & $9(19.1 \%)$ & $0.458(0.709)$ \\
\hline $\begin{array}{l}\text { Total abnormal } \\
\text { cases }\end{array}$ & $48(54.5 \%)$ & $28(59.5 \%)$ & \\
\hline
\end{tabular}

Laparoscopy revealed abnormal findings in 45(51.1\%) patients of primary infertility and $24(51 \%)$ patients of secondary infertility. Tubal occlusion was seen in 54 $(40 \%)$ patients whereas pelvic inflammatory disease was seen in $25(18.5 \%)$ patients. About $11(8.1 \%)$ patients had ovarian pathology. Six $(4.4 \%)$ patients had endometriosis and $6(4.4 \%)$ patients had distorted uterus. None of the values between primary and secondary infertility were statistically significant (Table 2).

Tubal block was seen in $36(40.9 \%)$ primary and 18 $(38.2 \%)$ secondary infertility cases. These were not statistically significant (Table 3 ).

Among women with primary infertility, intrauterine pathologies were diagnosed in $15(17.04 \%)$ cases. The congenital malformations were found in $8(53.3 \%)$ cases out of which septate uterus was seen in 6 cases. The acquired intrauterine pathologies were diagnosed in 7 $(46.6 \%)$ cases. Considering the group with secondary infertility, intrauterine pathologies were diagnosed in 13 $(27.65 \%)$ cases. The congenital uterine malformations were found in $5(38.4 \%)$ cases, all had uterine septum. The acquired intrauterine pathologies were diagnosed in $8(61.5 \%)$ cases. Hysteroscopic findings are also comparable between both the groups (Table 4). 
Table 3: Prevalence of tubal block by laparoscopic chromopertubation.

Table 2: Laparoscopy findings occurred alone or in combination.

\begin{tabular}{|c|c|c|c|c|}
\hline Findings & $\begin{array}{l}\text { Primary } \\
\text { infertility } \\
88(65 \%)\end{array}$ & $\begin{array}{l}\text { Secondary } \\
\text { infertility } \\
47(34.5 \%)\end{array}$ & $\begin{array}{l}\text { Total } \\
\text { cases } \\
135\end{array}$ & $\begin{array}{l}\mathbf{P} \\
\text { value }\end{array}$ \\
\hline Tubal block & $36(40.9)$ & $18(38.2)$ & \multirow{5}{*}{$\begin{array}{l}54 \\
(40 \%)\end{array}$} & \multirow{5}{*}{0.854} \\
\hline $\begin{array}{l}\text { Tubal block } \\
\text { without } \\
\text { adhesions }\end{array}$ & 21 & 11 & & \\
\hline $\begin{array}{l}\text { Tubal block } \\
\text { with } \\
\text { adhesions }\end{array}$ & 3 & 5 & & \\
\hline $\begin{array}{l}\text { Tubal block } \\
\text { with TO mass }\end{array}$ & 10 & 1 & & \\
\hline $\begin{array}{l}\text { Tubal block } \\
\text { with } \\
\text { endometriosis }\end{array}$ & 2 & 1 & & \\
\hline $\begin{array}{l}\text { Ovarian } \\
\text { pathology }\end{array}$ & $8(9)$ & $3(6.38)$ & \multirow{3}{*}{$\begin{array}{l}11 \\
(8.1 \%)\end{array}$} & \multirow{3}{*}{0.747} \\
\hline $\begin{array}{l}\text { Polycystic } \\
\text { ovaries }\end{array}$ & 4 & 3 & & \\
\hline $\begin{array}{l}\text { Simple } \\
\text { ovarian cyst }\end{array}$ & 4 & 0 & & \\
\hline $\begin{array}{l}\text { Pelvic } \\
\text { inflammatory } \\
\text { disease }\end{array}$ & $14(16.9)$ & $11(23.4)$ & \multirow{4}{*}{$\begin{array}{l}25 \\
(18.5 \%)\end{array}$} & \multirow{4}{*}{0.353} \\
\hline $\begin{array}{l}\text { Pelvic } \\
\text { adhesions }\end{array}$ & 7 & 7 & & \\
\hline $\begin{array}{l}\text { Pelvic } \\
\text { adhesions } \\
\text { with TO } \\
\text { mass }\end{array}$ & 6 & 3 & & \\
\hline $\begin{array}{l}\text { Pelvic } \\
\text { tuberculosis } \\
\text { with beaded } \\
\text { tubes }\end{array}$ & 1 & 1 & & \\
\hline Endometriosis & $3(3.4)$ & $3(6.38)$ & \multirow{3}{*}{$\begin{array}{l}6 \\
(4.4 \%)\end{array}$} & \multirow{3}{*}{0.419} \\
\hline $\begin{array}{l}\text { Endometriosis } \\
\text { of ovary }\end{array}$ & 1 & 2 & & \\
\hline $\begin{array}{l}\text { Pelvic } \\
\text { endometriosis }\end{array}$ & 2 & 1 & & \\
\hline $\begin{array}{l}\text { Uterine } \\
\text { pathology }\end{array}$ & $2(2.2)$ & $4(8.5)$ & \multirow{3}{*}{$\begin{array}{l}6 \\
(4.4 \%)\end{array}$} & \multirow{3}{*}{0.182} \\
\hline $\begin{array}{l}\text { Distorted } \\
\text { uterus by } \\
\text { fibroid }\end{array}$ & 1 & 3 & & \\
\hline $\begin{array}{l}\text { Distorted } \\
\text { uterus by } \\
\text { adhesions }\end{array}$ & 1 & 1 & & \\
\hline
\end{tabular}

\begin{tabular}{|lllll|} 
Finding & $\begin{array}{l}\text { Primary } \\
\text { infertility } \\
(88)\end{array}$ & $\begin{array}{l}\text { Secondary } \\
\text { infertility } \\
(47)\end{array}$ & $\begin{array}{l}\text { Total } \\
\text { cases } \\
(135)\end{array}$ & $\begin{array}{l}\text { P } \\
\text { value }\end{array}$ \\
\begin{tabular}{lllll|} 
Unilateral \\
block
\end{tabular} & 10 & 6 & $\begin{array}{l}16 \\
(11.8 \%)\end{array}$ & 0.787 \\
\hline $\begin{array}{l}\text { Bilateral } \\
\text { block }\end{array}$ & 26 & 12 & $\begin{array}{l}38 \\
(28.1 \%)\end{array}$ & 0.691 \\
\hline Total & $36(40.9 \%)$ & $18(38.2 \%)$ & $\begin{array}{l}54 \\
(40 \%)\end{array}$ & \\
\hline
\end{tabular}

Table 4: Hysteroscopy findings occurred alone or in combination.

\begin{tabular}{|lllll|}
\hline $\begin{array}{l}\text { Findings } \\
(\%)\end{array}$ & $\begin{array}{l}\text { Primary } \\
\text { infertility } \\
(88)\end{array}$ & $\begin{array}{l}\text { Secondary } \\
\text { infertility } \\
(47)\end{array}$ & $\begin{array}{l}\text { Total } \\
\text { cases }\end{array}$ & $\begin{array}{l}\text { P } \\
\text { value }\end{array}$ \\
\hline $\begin{array}{l}\text { Uterine } \\
\text { anomaly }\end{array}$ & $8(53.3 \%)$ & $5(38.4 \%)$ & $\begin{array}{l}13 \\
(9.6 \%)\end{array}$ & 0.767 \\
\hline $\begin{array}{l}\text { Myoma / } \\
\text { Polyp }\end{array}$ & $4(26.6 \%)$ & $3(23 \%)$ & $\begin{array}{l}7 \\
(5.1 \%)\end{array}$ & 0.694 \\
\hline Synechiae & $1(6.6 \%)$ & $4(30.7 \%)$ & $\begin{array}{l}5 \\
(3.7 \%)\end{array}$ & 0.050 \\
\hline $\begin{array}{l}\text { Blocked / } \\
\begin{array}{l}\text { Fibrosed } \\
\text { Ostium }\end{array}\end{array}$ & $3(20 \%)$ & $4(30.7 \%)$ & $\begin{array}{l}7 \\
(5.1 \%)\end{array}$ & 0.237 \\
\hline $\begin{array}{l}\text { Foreign body } \\
\text { with irregular } \\
\text { endometrium }\end{array}$ & 0 & $1(1.1 \%)$ & $\begin{array}{l}1 \\
(<1 \%)\end{array}$ & 0.348 \\
\hline
\end{tabular}

\section{DISCUSSION}

Infertile women with normal ovulatory cycles, seminogram and hormonal profiles have higher possibility of having tuboperitoneal and subtle endometrial pathologies. These women undergo emotional and financial trauma with anxiety while undergoing series of procedures like HSG, receiving treatment for timing ovulation with coitus, controlled ovulation stimulation with follicular tracing by transvaginal ultrasound, laparoscopy and hysteroscopy over a period of time before being referred for ART. Performing hysterolaparoscopy as single step procedure straightway in these may be more productive. Hysterolaparoscopy may initially appear to be expensive, invasive and require anaesthesia but subsequently, it may prove to be more fruitful as therapeutic interventions or early decisions for ART or both can be undertaken simultaneously.

Diagnostic hysteroscopy is also a proven method for investigating the cause of female infertility. Uterine pathologies can be the contributing factor for infertility in as many as $15 \%$ of couples seeking treatment and are diagnosed in as many as $50 \%$ of infertile patients. ${ }^{4-7}$ Association of congenital uterine anomalies with pregnancy loss and obstetrics complications have been 
seen for a long time but the ability to conceive is generally not affected.

Mean prevalence of uterine malformation in general population and in the population of fertile women is approximately $4.3 \%$, in infertile patients $3.5 \%$ and in patients with recurrent pregnancy losses approximately $13 \%{ }^{8}$ Septate uterus is the most common uterine anomaly with a mean incidence of approximately $37.15 \%$ followed by bicornuate uterus approximately $26.13 \%$ and arcuate uterus approximately $21.26 \%$ of uterine anomaly in infertile couple. ${ }^{9}$ Our study shows that the incidence of uterine anomaly was $13(9.6 \%)$, septate uterus is the most common anomaly with a mean incidence of approximately $11(84 \%)$ followed by bicornuate uterus 1 $(7.6 \%)$ and cervical stenosis $1(7.6 \%)$. Septate uterus has been recognized as most common cause associated with highest reproductive failure rates. The reproductive performance of women with an uncorrected septum is rather poor, as $65 \%$ losses occur in the first trimester. ${ }^{10}$ Pregnancy outcomes also dramatically improve after surgical correction of septate uterus with $80 \%$ term delivery, $5 \%$ preterm delivery and $15 \%$ pregnancy loss. ${ }^{11}$ Operative hysteroscopy technique which is performed as a day care procedure nowadays is recommended for septal resection as it carries a low morbidity. Our study also revealed myoma and polyp in $7(5.1 \%)$, synechia in $5(3.7 \%)$, blocked or fibrosed ostium in $7(5.1 \%)$, foreign bodies with irregular endometrium in $1(0.74 \%)$ infertile patients. In infertile patients about $20 \%$ of hysteroscopic examination shows some grade of intrauterine abnormalities. ${ }^{11}$ This is at par with our study $20.7 \%$ (28/135). In a study comparing hysteroscopy with HSG, the latter showed a false negative rate of $12 \%$ and the complication rate of diagnostic hysteroscopy can be as low as $0.012 \% .^{12,13}$

Laparoscopy is extremely useful in decision making while dealing with infertility of prolonged duration and older women. ${ }^{14}$ In a retrospective study of 495 infertile women with unexplained infertility, laparoscopy before starting treatment revealed a significant incidence of abnormalities resulting a changed in decision. ${ }^{15}$ Similarly when patients with unexplained infertility following standard infertility screening tests underwent diagnostic laparoscopy, 21-68\% of these patients were found to have pathologic abnormalities which included endometriosis and tubal disease. ${ }^{14,16,17}$ Our results at laparoscopy and dye studies had shown bilateral tubal patency in 79 (58.5\%), bilateral tubal block in 38 (28.1\%) and unilateral tubal block in $16(11.8 \%)$ of infertile patients. In three patients because of cervical stenosis and suspected tuberculosis, laparoscopic dye study was not done. In one study at laparoscopy, bilateral tubal patency was demonstrated in $86.67 \%$, bilateral tubal block in $5 \%$ and unilateral block in $8.33 \%$ of patients. ${ }^{9}$ We got nearly equal prevalence of tubal block in primary infertility patients $(40.9 \%)$ and secondary infertility patients $(38.2 \%)$ which was similar to study done by Nayak KP et al. ${ }^{18}$ In our study pelvic pathology by laparoscopy was confirmed in $54.5 \%$ of our cases, which was similar to other studies. ${ }^{16,17}$ In the present study, tubal block was the most common pathology (40\%), followed by pelvic inflammatory disease $(18.5 \%)$. Ovarian pathology comprised $8.1 \%$ whereas pelvic endometriosis $4.4 \%$ and distorted uterus was also $4.4 \%$ of infertile cases diagnosed by laparoscopy.

Thus, diagnostic laparoscopy is the standard means of diagnosing the tubal pathology, peritoneal factors, ovarian factors and uterine factors as cause of infertility. In a comparative study between HSG and laparoscopy done by La Sala et al. for evaluation of tuboperitoneal factors had shown a false negative rate $35.5 \%$ and false positive rate of $37.7 \%$ for HSG and Snowden et al also in their study obtained the false negative rate of $13 \%$ and false positive rate of $16 \%$ for HSG. ${ }^{19}$ Treatment modalities at the time of laparoscopy comprised of adhesiolysis, ablation of endometriosis, ovarian drilling and ovarian cystectomy. Hysteroscopic interventions were proximal tubal cannulation, septoplasty, synecolysis and myomectomy. Infertile cases with unilateral tubal block were advised further treatment in the form of superovulation with IUI for 3-6 cycles. Hysterlaparoscopy detected, 20 cases of uncorrected bilateral tubal block and 14 cases of severe grade of pelvic disease with bilateral tubal block who were referred for IVF-ET without any further delay. Women with corrected pathologies in hysterolaparoscopy were given trials for spontaneous conception for a period of 6 months.

As a whole, pelvic pathologies were confirmed in $54.5 \%$ of patients and intrauterine pathologies in $20.7 \%$ of patients by simultaneous diagnostic hysterolaparoscopy. With the view of the low complication rate, minimal time requirements, dealing the abnormal finding therapeutically at the same sitting, a negligible effect in the postoperative course and significant advantage over HSG, hysterolaparoscopy should be carried in all patients to look for tubal and pelvic cause of infertility when all other examinations performed were normal.

\section{CONCLUSION}

It can be concluded that diagnostic hysterolaparoscopy is effective and safe tool in evaluation of all infertile patients to look for tubal or pelvic cause of infertility when all other examinations performed were normal. It will also be possible in formulating a specific plan of management and segregate the patients who will need ART at the earliest, thus avoiding further emotional and financial trauma to the couples. Our study is retrospective in nature with limited sample size hence we suggest more studies in this aspect of infertility.

\section{Funding: No funding sources Conflict of interest: None declared}

Ethical approval: The study was approved by the institutional ethics committee 


\section{REFERENCES}

1. Jahan S. Role of laparoscopy in infertility: review article. Birdem Med J. 2012;2:99-103.

2. Howkins, Bourine. The pathology of conception. In: Howkins, Bourine, eds. Shaw's Text Book of Gynaecology. 13th ed. US: Elsevier; 2004.

3. Hucke J, De Bruyme T, Balan P. Hysteroscopy in infertility - diagnosis and treatment including falloscopy. Gynecol Obstet. 2000;20:13-20.

4. Wallach EE. The uterine factor in infertility. Fertil Steril. 1972;23:138-58.

5. Brown SE, Coddington C, Schnorr J, Toner JP, Gibbons W, Oehinger S. Evaluation of outpatient's hysteroscopy, saline infusion hysterosonography and hysterosalpingography in infertile women: A prospective randomized study. Fertil Steril. 2000;74:1029-34

6. Puri S, Jain D, Puri S, Kaushal S, Deol SK. Laparohysteroscopy in female infertility: a diagnostic cum therapeutic tool in Indian setting. Int J App Basic Med Res. 2015;5:46-8.

7. Mooney SD, Milki AA. Effect of hysteroscopy performed in the cycle preceding controlled ovarian hyperstimulation on the outcome of in vitro fertilization. Fertil Steril. 2003;76:637-8.

8. Grimbizis GF, Camns M, Tariazis BC, Bonits JN, Devroey P. Clinical implications of uterine malformations and hysteroscopic treatment results. Hum Reprod. 2001;7:161-74.

9. Godinjak Z, Idrizbegovic E. Should diagnostic hysteroscopy be a routine procedure during diagnostic laparoscopy in infertile women? Bosnian J Basic Med. 2008;8:44-7.

10. Homer HA, Li TC, Cooke ID. The septate uterus a review of management and reproductive outcome. Fertil Steril. 2000;73:1-4.

11. Zhang E, Zhang Y, Fang L, Li Q, Gu J. Combined hysterolaparoscopy for the diagnosis of female infertility: a retrospective study of 132 patients in china. Mater Sociomed. 2014 Jun;26(3):156-7.
12. Hourvitz A, Ledee H, Gervaizw A, Fernandez H, Frydman R, Olivenness F. Should diagnostic hysteroscopy in women with normal hysterosalpingography? Reprod Biomed. 2002;4:256-60.

13. Jansen FW, Vredevooged CB, Van Uzlen K, Hermans J, Trimbas JB, Trimbas Kemper TC. Complications of hysteroscopy: a prospective multicoated study. Obstet Gynecol. 2000;96:266-70.

14. Corson SL, Cheng A, Gotman JN. Laparoscopy in the normal infertile patient: a question revised. J Am Assoc Gynecol Laparosc. 2000;7:317-24.

15. Tanahatoe SJ, Hompes PG, Lambalk CB. Investigation of the infertile couple: should diagnostic laparoscopy be performed in the infertility workup programme in patients undergoing interuterine insemination? Hum Reprod. 2003;18:811.

16. Cundiff G, Car BR, Marshborn PB. Infertile couples with a normal hysterosalpingogram reproductive outcome and its relationship to clinical and laparoscopic finding. J Reprod Med. 1995;40:19-24.

17. Tsuji I, Ami K, Mujazaki A, Hujinami N, Hoshiai H. Benefit of diagnostic laparoscopy for patients with unexplained infertility and normal hysterosalphingography finding. Tohaku J Exp Med. 2009;219:239-42.

18. Nayak KP, Mahapatra P, Mallick JJ, Swain S, Mitra $\mathrm{S}$, Sahoo J. Role of diagnostic hysterlaparoscopy in the evaluation of infertility: a retrospective study of 300 patients. J Hum Reprod Sci. 2013;6:32-4.

19. Vaid K, Mehra S, Verma M, Jain S, Sharma A, Bhaskaran S. Pan endoscopic approach "hysterolaparoscopy" as an initial procedure in selected infertile women. J Clin Diagn Res. 2014;8(2):95-8.

DOI: 10.18203/2320-1770.ijrcog20150056

Cite this article as: Begum J, Samal S, Ghose S, Pallavee P, Samal R. Combined hysterolaparoscopy as an early option for initial evaluation of female infertility: a retrospective study of 135 patients. Int J Reprod Contracept Obstet Gynecol 2015;4:584-8. 